\title{
Effect of Potassium Silicate Application on Populations of Asian Citrus Psyllid in Tahiti Lime
}

\author{
Augusto Ramírez-Godoy, María del Pilar Vera-Hoyos, \\ Natalia Jiménez-Beltrán, and Hermann Restrepo-Díaz ${ }^{1}$
}

AdDITIONAL INDEX wORDs. Diaphorina citri, foliar silicon concentration, integrated pest management, plant herbivory, sucking insects, host defense mechanisms

SuMmary. Asian citrus psyllid [ACP (Diaphorina citvi)] is one of the most serious threats to the global citrus (Citrus sp.) culture, and management of ACP has depended primarily on the application of chemical insecticides. The expression of resistance mechanisms to herbivory is a key component in integrated pest management in crop production in which silicon (Si) applications can play an important role in plant-insect relationships. The objective of the current study was to evaluate the application of Si to tahiti lime (Citrus latifolia) plants under natural infestations of ACP. Two experiments were conducted using 15-month-old seedlings and 2 -year-old trees, respectively. Treatments were 1) foliar Si sprays (potassium silicate) at a dose of $\left.2 \mathrm{~mL} \cdot \mathrm{L}^{-1}, 2\right)$ soil $\mathrm{Si}$ application at a dose of $1 \mathrm{~kg}$ commercial product per plant, 3) combined soil and foliar applications of $\mathrm{Si}$ at the doses just listed, and 4) untreated plants (control). The application of Si treatments to both seedlings and trees affected ACP oviposition, causing a reduction of $60 \%$. Applications of Si did not affect the nutritional status (macronutrients and micronutrients) of plants in either test, except that the foliar concentration of $\mathrm{Si}$ tended to be greater in the soil and soil + foliar treatments than in the other treatment in both seedlings and trees. Based on these results, we suggest that $\mathrm{Si}$ can be added as a component of ACP integrated pest management programs.

$\mathrm{R}$

elationships among fertilizer applications and pest populations are described in the scientific literature, particularly in response to nitrogen $(\mathrm{N})$ fertilization (Rashid et al., 2017; Singh and Sood, 2017). However, Si application has acquired importance because of its role as a beneficial element in the mitigation of both abiotic and biotic plant stresses during recent years (Marschner, 2012; Reynolds et al., 2016).

Si plays an important role in mediating resistance to a wide range of biotic stresses caused by plant pathogens and insect pests (Debona et al., 2017). The use of Si has been

Departamento de Agronomía, Facultad de Ciencias Agrarias, Universidad Nacional de Colombia, Bogotá, Colombia

The paper is a portion of a thesis submitted by Augusto Ramírez-Godoy in fulfilling a $\mathrm{PhD}$ degree requirement.

Mention of a trademark, proprietary product, or vendor does not constitute a guarantee or warranty of the product by the authors or Universidad Nacional de Colombia, and does not imply its approval to the exclusion of other products or vendors that also may be suitable.

${ }^{1}$ Corresponding author. E-mail: hrestrepod@unal. edu.co.

https://doi.org/10.21273/HORTTECH04066-18 reported as a promoter of plant resistance to pest attack (Reynolds et al., 2009; Stenberg, 2017; Teixeira et al., 2017; Yang et al., 2017). Si forms a physical barrier on the leaf, conferring resistance to herbivory by modulating the sedimentation of callose in the sieve tube elements in the plant, the biosynthesis of secondary metabolites, and the regulation of jasmonic acid, all of which are associated with plant defense mechanisms (Yang et al., 2017, 2018; Ye et al., 2013).

Si application can be deposited in intra- and intercellular spaces after plant uptake, and its accumulation can affect herbivorous arthropods directly and indirectly (Pozza et al., 2015; Reynolds et al., 2016; Yang et al., 2017). Si accumulation can act directly, leading to a reduction in insect performance and plant damage, whereas indirect effects delay herbivore establishment (Reynolds et al., 2009).

The addition of $\mathrm{Si}$ has reduced plant damage and/or population densities caused by chewing insects [e.g., fall armyworm (Spodoptera frugiperda) and american grasshopper (Schistocerca americana) (Nabity et al., 2012; Nascimento et al., 2018)] and sucking insects [e.g., green peach aphid (Myzus persicae) and spittlebugs (Mahanarva fimbriolata) (Korndörfer et al., 2011; Ranger et al., 2009)]. However, Si application has been reported to reduce mainly oviposition (Reynolds et al., 2009). Studies have concluded that an Si supply affected oviposition preference negatively the tobacco whitefly (Bemisia tabaci) in the common bean [Phaseolus vulgaris (Peixoto et al., 2011)] and the cucurbit beetle (Diabrotica speciosa) in potato [Solanum tuberosum (Assis et al., 2012)].

Si has been supplied via soil or in sprays for the management of herbivores in dicotyledon crops such as cotton (Gossypium hyrsutum), cucumber (Cucumis satious), and tomato (Solanum lycopersicum) (Reynolds et al., 2016). In this context, foliar Si applications increased the mortality of tobacco whitefly nymphs on cucumber (Cucumis satipus) (Correa et al., 2005). Soil fertilization with calcium $(\mathrm{Ca})$ or potassium silicate favored resistance to arthropods in wheat (Triticum aestivum) and citrus plants by decreasing population density or increasing leaf $\mathrm{Si}$ concentration, respectively (Gomes et al., 2005;

\begin{tabular}{llll}
\hline $\begin{array}{l}\text { Units } \\
\text { To convert U.S. to SI, } \\
\text { multiply by }\end{array}$ & U.S. unit & SI unit & $\begin{array}{l}\text { To convert SI to U.S., } \\
\text { multiply by }\end{array}$ \\
\hline 29.5735 & $\mathrm{fl} \mathrm{oz}$ & $\mathrm{mL}$ & 0.0338 \\
0.3048 & $\mathrm{ft}$ & $\mathrm{m}$ & 3.2808 \\
3.7854 & gal & $\mathrm{L}$ & 0.2642 \\
2.54 & inch $(\mathrm{es})$ & $\mathrm{cm}$ & 0.3937 \\
25.4 & inch $(\mathrm{es})$ & $\mathrm{mm}$ & 0.0394 \\
0.4536 & $\mathrm{lb}$ & $\mathrm{kg}$ & 2.2046 \\
28.3495 & $\mathrm{oz}$ & $\mathrm{g}$ & 0.0353 \\
0.001 & $\mathrm{ppm}$ & $\mathrm{g} \cdot \mathrm{kg}^{-1}$ & 1000 \\
1 & $\mathrm{ppm}$ & $\mathrm{mg} \cdot \mathrm{kg}^{-1}$ & 1 \\
0.001 & $\mathrm{ppm}$ & $\mathrm{mL} \cdot \mathrm{L}^{-1}$ & 1000 \\
$\left({ }^{\circ} \mathrm{F}-32\right) \div 1.8$ & ${ }^{\circ} \mathrm{F}$ & ${ }^{\circ} \mathrm{C}$ & $\left({ }^{\circ} \mathrm{C} \times 1.8\right)+32$
\end{tabular}


Matichenkov et al., 1999). Soil Si supply also caused a population reduction around $60 \%$ in cotton bollworm (Pectinophora gossypiella) (El-Ghobary and El-Samahy, 2015). Last, a previous study also showed that soil or foliar potassium silicate applications caused a decrease in the total number of ACP individuals (i.e., adults, nymphs, and eggs) in tahiti lime trees (Ramírez-Godoy et al., 2018).

Combined Si application (soil + foliar) may also increase plant resistance. Assis et al. (2013) found that soil and foliar Si applications increased the mortality of sunflower patch (Chlosyne lacinia) larvae $\approx 10 \%$ compared with that with soil application alone on sunflower (Helianthus annuus) plants, concluding that this combined strategy conferred resistance to sunflower plants because of a greater Si accumulation, which affected leaf palatability. In addition, De Queiroz et al. (2016) observed that soil and foliar $\mathrm{Si}$ applications mainly decreased red gum lerp psyllid (Glycaspis brimblecombei) oviposition in river red gum (Eucalyptus camaldulensis).

ACP is currently the most important pest for global citriculture as the vector responsible for transmitting the bacterial pathogen Candidatus Liberibacter asiaticus and Candidatus Liberibacter americanus, which cause Huanglongbing disease (HLB) (Halbert et al., 2000). ACP feeds primarily on the phloem in new flush shoots, young leaves, and mature leaves (Luo et al., 2015). Yang et al. (2017) noted that Si amendment induces defense responses against insects that feed on the phloem. Si can interfere with the feeding habit of sucking insects because the movement and penetration of the stylet can be limited by the intracellular accumulation of this element (Ranger et al., 2009). Also, the development of alternative management strategies that favor host plant resistance to this insect pest could improve integrated management programs significantly against ACP (Hall et al., 2013). Consequently, it can be hypothesized that Si application may have effects on pest management of disease vectors like ACP by affecting the pest through its oviposition preference.

For ACP management, growers have focused primarily on the application of chemical insecticides (neonicotinoids and pyrethroids group) to protect orchards and nurseries as a result of their quick activity and broad spectrum (Chen and Stelinski, 2017; Stansly and Rogers, 2006; Tiwari et al., 2011). The continuous use of insecticides has increased the episodes of resistance in ACP populations, which have decreased the effectiveness of insecticides in citrus-growing regions such as Florida and Texas

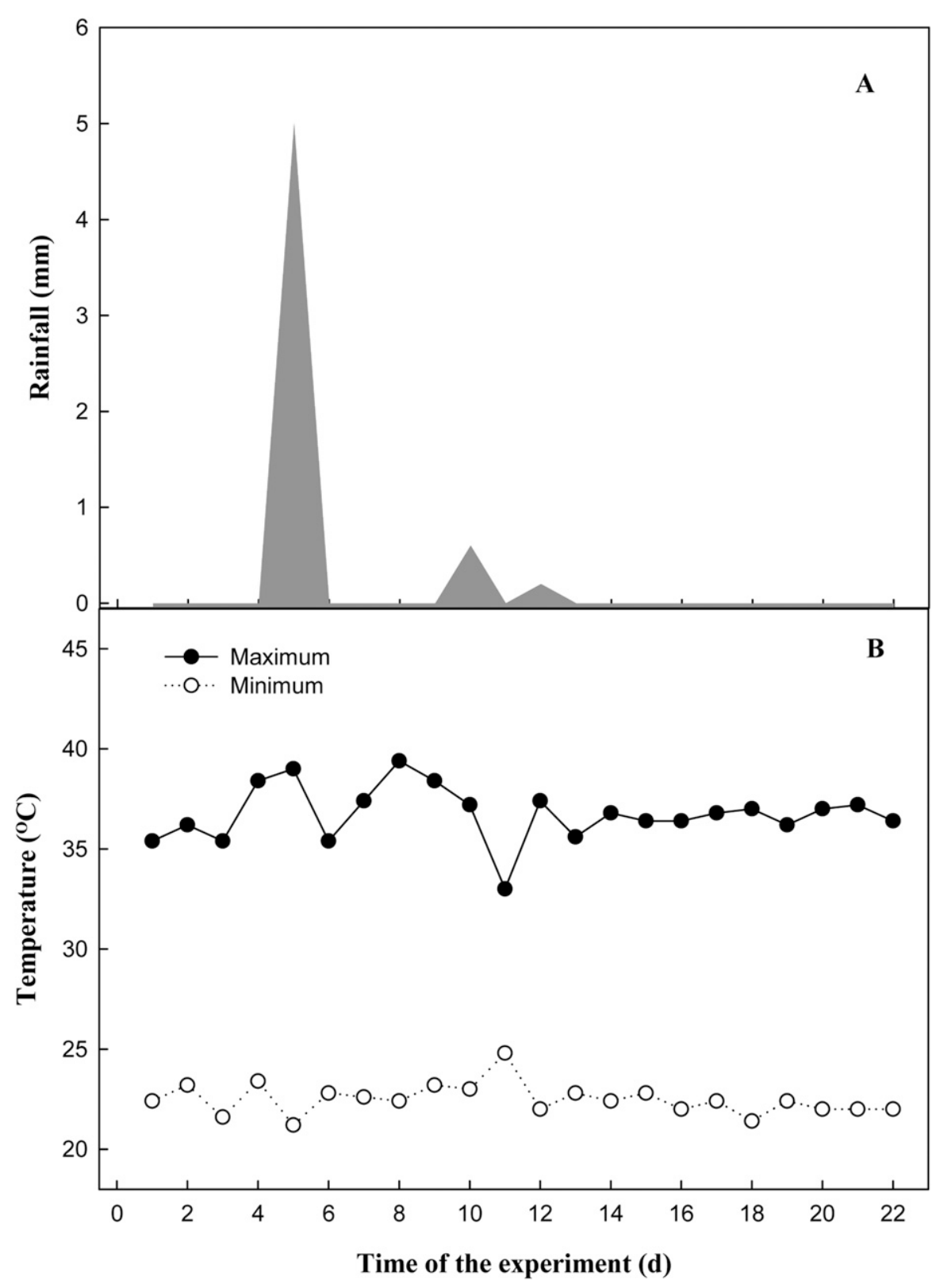

Fig. 1. Records of (A) precipitation and (B) maximum and minimum temperatures for the evaluation trial of silicon applications on the control of populations of asian citrus psyllid on tahiti lime trees. Data were obtained from a nearby weather station [Jerusalen station: lat. $4^{\circ} 56^{\prime} 18.06 " \mathrm{~N}$, long. $74^{\circ} 70^{\prime} 23.99 \prime \prime \mathrm{W}$; altitude, $297 \mathrm{~m}$ (974.4 ft)] of the Institute of Hydrology, Meteorology and Environmental Studies of Colombia (IDEAM, Bogotá, Colombia). $1 \mathrm{~mm}=0.0394$ inch; $\left(1.8 \times{ }^{\circ} \mathrm{C}\right)+32={ }^{\circ} \mathrm{F}$.
(Boina and Bloomquist, 2015). In addition, populations of natural enemies that contribute to ACP control are affected by the high use of chemical insecticides (Hall et al., 2013). Si fertilization does not cause toxic residues in food or in the environment, is relatively low cost, and could be integrated easily into other pest management strategies such as biologic, chemical, and cultural practices (Laing et al., 2006). Moreover, the 
use of $\mathrm{Si}$ could be an alternative practice to ACP control because integrated management strategies are required by citrus growers (Khan et al., 2015).

ACP was officially reported in Colombia in 2007 (Santivañez et al., 2013). In 2015, the Colombian Agricultural Institute declared a phytosanitary emergency status as a result of the presence of ACP adults infected with the bacteria that cause HLB disease (Colombian Agricultural Institute, 2015). However, reports suggesting the use of $\mathrm{Si}$ as an inducer of resistance against ACP in citrus trees are scarce both locally and internationally (Krajewski and Krajewski, 2011). Therefore, the objective of this study was to evaluate the effect of different applications of Si fertilization (soil, sprays, and soil + sprays) on ACP populations (adults, nymphs, and eggs) either in seedlings or trees under natural infestation, as well as to quantify how these treatments could affect the leaf nutritional status (macronutrient, micronutrient, and $\mathrm{Si}$ concentration) and attractiveness to the pest in tahiti lime seedlings and trees, because $\mathrm{Si}$ use may provide further protection in potting media or orchard conditions.

\section{Materials and methods}

Two separate experiments on seedlings and field-grown trees were carried out to estimate the effect of potassium silicate applications (foliar, soil, or combined) on ACP population density under dry forest conditions.

SeEDLings. A preliminary experiment was conducted for 4 weeks (June and July 2017) at the farm "La Rochela" (lat. 4'33'22.1"N, long. $74^{\circ} 43^{\prime} 36.8^{\prime \prime} \mathrm{W}$; altitude, $305 \mathrm{~m}$ ) in the municipality of Jerusalen in Colombia. Timing of the study was selected based on previous observations of ACP activity in this region (Ramírez-Godoy et al., 2018). Tahiti lime seedlings were purchased from a local wholesale nursery. Plants were grown in plastic bags containing a 1:1:1 mixture of native soil, sand, and rice husks. This substrate is commonly used by commercial nurseries in Colombia. Fifteen-month-old tahiti lime seedlings grafted onto 'CPB 4475' citrumelo (Citrus paradisi $\times$ Poncirus trifoliata) were used in this experiment and were fertilized previously using a $15 \mathrm{~N}-6.5 \mathrm{P}-12.5 \mathrm{~K}$ fertilizer (Ingeplant, Mosquera, Colombia). To increase the likelihood of a natural ACP infestation, the seedlings were placed on the borders of a commercial tahiti lime orchard. Sétamou et al. (2008) stated that this insect tends to be more prevalent at the edges of orchards. The distance between seedlings was $5 \mathrm{~m}$ to cover the entire orchard. Seedlings were irrigated three times per week with $500 \mathrm{~mL}$ water.

Experimental units were groups of three seedlings (per treatment per block) for a total of 12 plants/treatment. Seedlings were inspected previously to guarantee they were ACP-free (adults, nymphs, and eggs) before the test started. The experiment was conducted at La Rochela, allowing natural infestations of ACP, because the Universidad Nacional (Bogotá campus) headquarters is located at $2600 \mathrm{~m}$ elevation, and this altitude does not allow for the proper development of ACP populations (Ebratt-Ravelo et al., 2011; Jenkins et al., 2015).

The treatments established in this preliminary test were 1 ) seedlings without Si treatment (control); 2) seedlings treated with foliar potassium silicate sprays (Nitrosil-K; Agromil, Ibagué, Colombia) at $2 \mathrm{~mL} \cdot \mathrm{L}^{-1}$; 3 ) soil potassium silicate application (Siliceo-K; Agromil) at $650 \mathrm{mg} /$ plant, which was equivalent to $1 \mathrm{~kg}$ of the commercial product; and 4) seedlings treated with soil and foliar potassium silicate applications at the doses just described.

At weeks 0 and 2 after the seedlings were placed in the orchard, foliar applications were performed between 0700 and 0800 HR with a backpack sprayer (using an application volume of $0.25 \mathrm{~L} /$ plant), wetting both the upper and lower surfaces of leaves. All foliar applications were made without adjuvant. The soil application was performed at the beginning of the test [ 0 week after treatment (WAT)], incorporating the Si fertilizer within the top $10 \mathrm{~cm}$ of the surface of the bag.

SILICON APPLICATION ON TAHITI LIME TREES. This test was also conducted on the same commercial orchard as the seedling test. The test used 2-year-old (trees were $1.50 \mathrm{~m}$ tall and their canopies were $1 \mathrm{~m}$ wide) field-grown tahiti lime trees grafted onto ' $\mathrm{CPB} 4475$ ' citrumelo. In

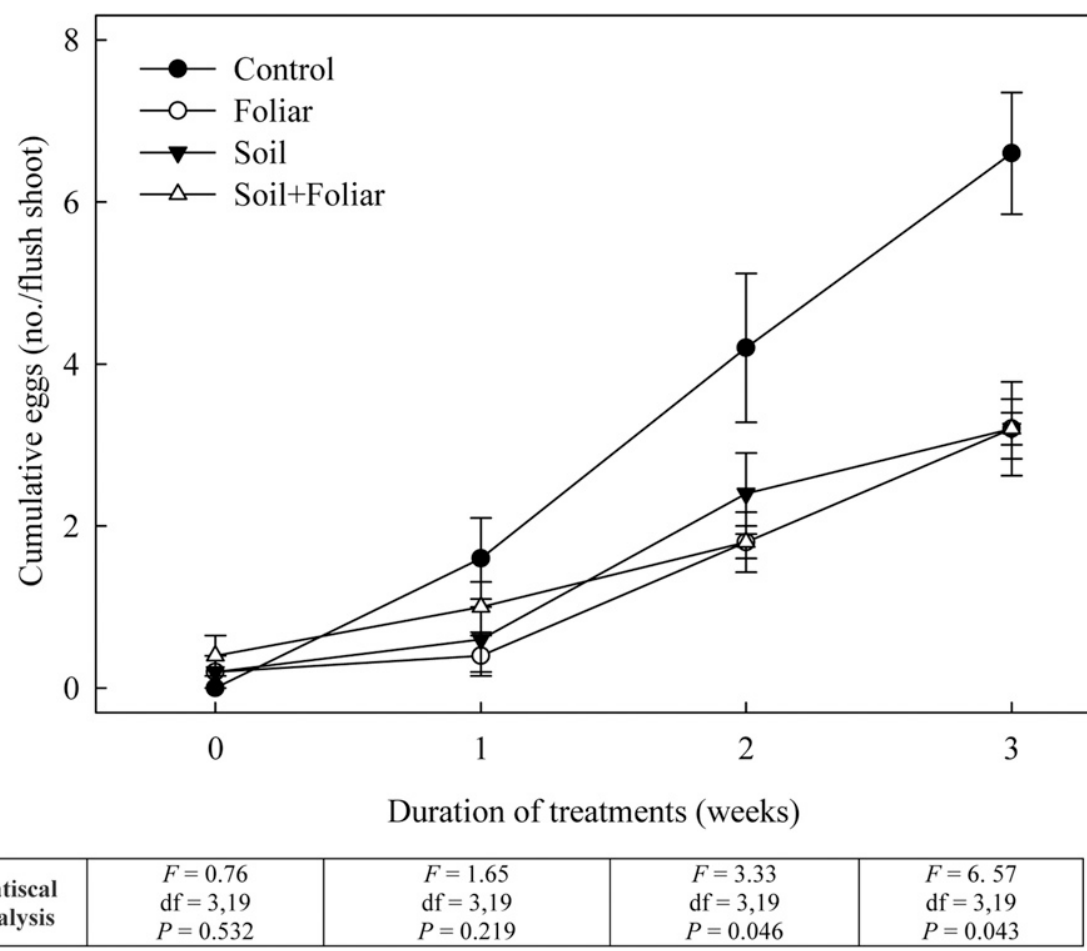

Fig. 2. Cumulative individuals of asian citrus psyllid (no. eggs/flush shoot) on tahiti lime seedlings with different silicon applications (control, foliar, soil, and soil + foliar). Each point represents the mean of four values. Vertical bars represent $\pm \mathrm{SE}$. 
addition, all trees were spaced at $8 \times$ $5 \mathrm{~m}$. This experiment also lasted 4 weeks and occurred between Aug. and Sept. 2017. The climatic conditions (rainfall and average temperature) during the experiment are presented in Fig. 1. Trees were managed according to the recommendations of Orduz-Rodríguez and Mateus (2012) for commercial citrus management in Colombia, which included rowcover crop maintenance, weed removal, nutrient management ( $15 \mathrm{~N}-$ $6.5 \mathrm{P}-12.5 \mathrm{~K}$ fertilizer at $200 \mathrm{~g} /$ tree), and fungicide application.

The experimental units were groups of three trees, which were surrounded by eight field-grown trees to minimize edge and application drift effects. The treatments were 1 ) trees without foliar or soil application of $\mathrm{Si}$ (control), 2) trees treated with foliar $\mathrm{Si}$ sprays at $2 \mathrm{~mL} \cdot \mathrm{L}^{-1}, 3$ ) trees treated with soil $\mathrm{Si}$ application at $1 \mathrm{~kg}$ of the commercial product, and 4 trees treated with both foliar and soil $\mathrm{Si}$ applications at the doses described earlier. In both tests, the combined treatment (soil + foliar) kept the same $\mathrm{Si}$ doses because of environmental and physiologic considerations. Warm daytime temperatures ( $>33$ ${ }^{\circ} \mathrm{C}$ ) and scant rainfall were recorded in our study region (Fig. 1), and are factors that condition foliar and soil nutrient uptake (Marschner, 2012). The Si doses (soil or spray applications) in both tests were used in this work because they showed positive results in a previous study (RamírezGodoy et al., 2018). In this test, foliar applications were also conducted at 0 and 2 WAT between 0700 and 0900 HR with a backpack sprayer (using an application volume of 2 $\mathrm{L} /$ tree), wetting both the upper and lower surfaces of leaves. All foliar applications were without adjuvant. The edaphic application was performed at the beginning of the test (0 WAT), with the fertilizer
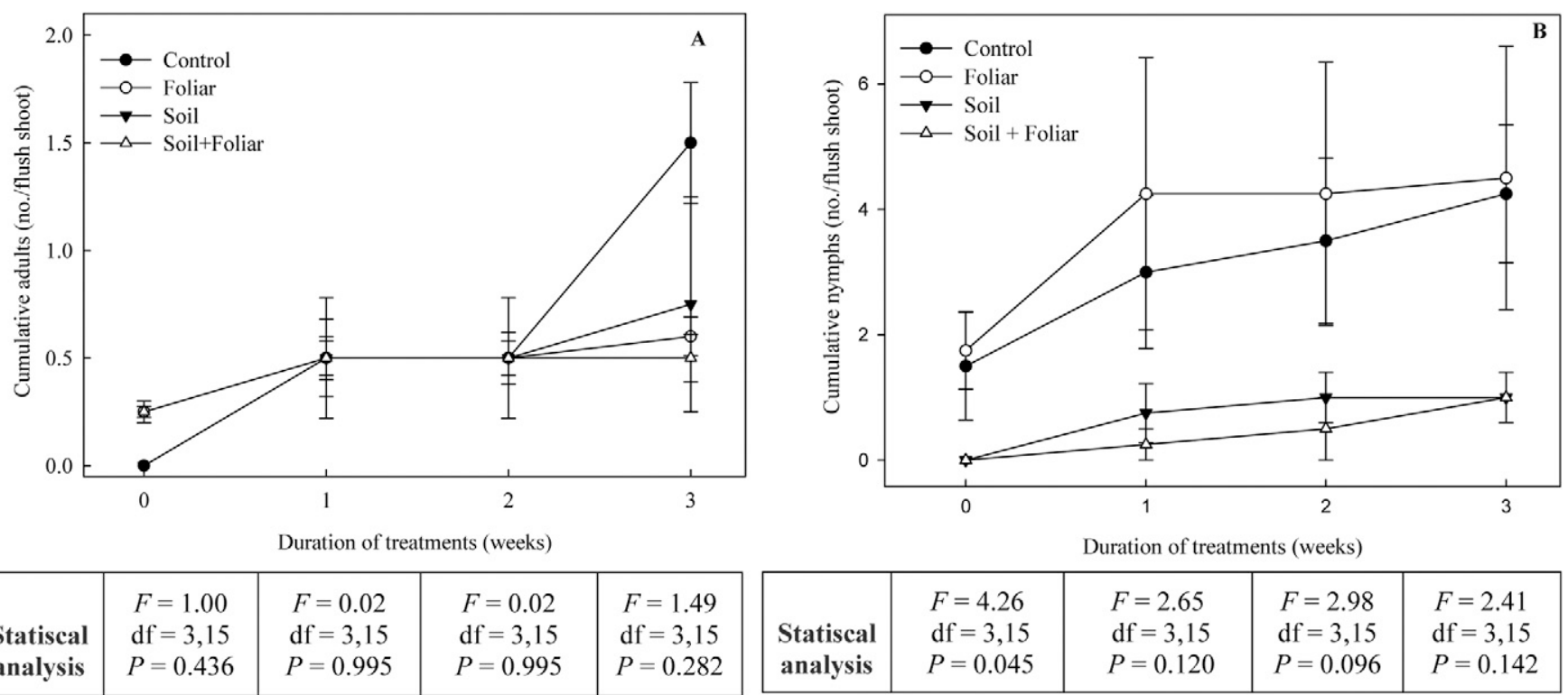

\begin{tabular}{|l|c|c|c|c|}
\hline & $F=1.00$ & $F=0.02$ & $F=0.02$ & $F=1.49$ \\
Statiscal & $\mathrm{df}=3,15$ & $\mathrm{df}=3,15$ & $\mathrm{df}=3,15$ & $\mathrm{df}=3,15$ \\
analysis & $P=0.436$ & $P=0.995$ & $P=0.995$ & $P=0.282$ \\
\hline
\end{tabular}

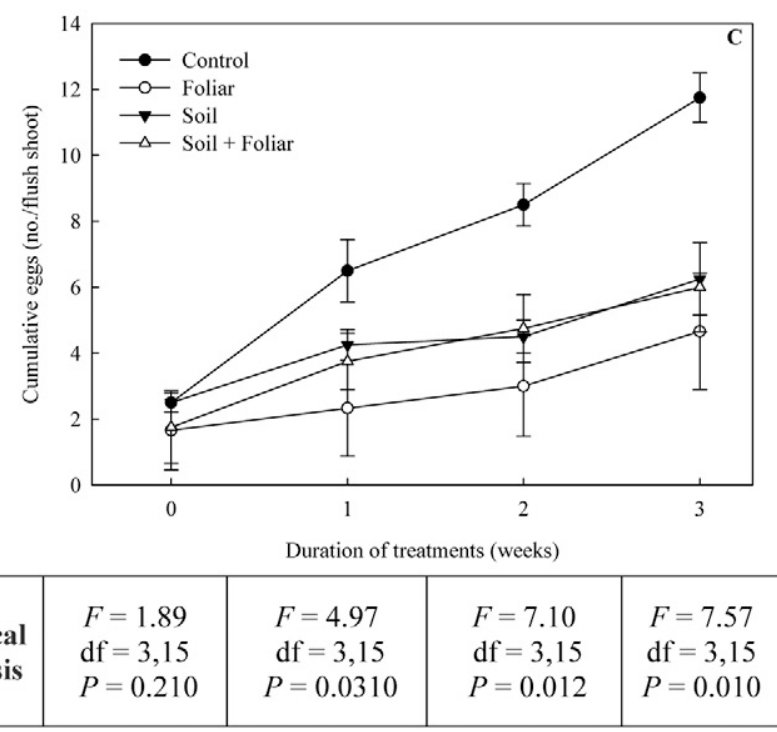

Fig. 3. Cumulative (A) adults, (B) nymphs, and (C) eggs of asian citrus psyllid on tahiti lime trees with different silicon applications (control, foliar, soil, and soil + foliar). Each point represents the mean of four values. Vertical bars represent \pm SE. 
incorporated within the first $30 \mathrm{~cm}$ under the crown of the tree.

ACP POPULATION DENSITY ON TREATED CITRUS PLANTS. In the test on seedlings, the mean number of ACP eggs was quantified only, because no adults or nymphs were observed at the time of the evaluations. Regarding the tree test, the methodology described by Sétamou et al. (2008) was also used to estimate the ACP population density. Relative infestation levels of ACP adults, eggs, and nymphs were estimated by inspecting four young shoots per tree at the four cardinal points. The mean number of ACP adults, nymphs, and eggs (individuals per shoot) was obtained. A $15 \times$ handheld magnification lens was used to count the eggs and nymphs in situ, with counts recorded by shoot. Samplings for both tests were conducted between 0 and 4 WAT at 7 -d intervals.

Foliar anALYsis. Leaf samples were collected at the end of both tests (4 WAT) to determine whether the application of $\mathrm{Si}$ affected the nutritional status of tahiti lime trees. In the test conducted on trees, 40 mature leaves were collected from each tree. Leaves were always collected from the middle portion of the season's terminal growth. In the test with seedlings, about five physiologically active leaves were collected from the crown of each seedling. In general, leaf samples from the same treatment of each block were combined and collected in paper bags to perform a complete foliar analysis $[\mathrm{N}$, phosphorus $(\mathrm{P})$, potassium $(\mathrm{K}), \mathrm{Ca}$, magnesium $(\mathrm{Mg})$, copper $(\mathrm{Cu})$, iron $(\mathrm{Fe})$, manganese $(\mathrm{Mn})$, boron $(\mathrm{B})$, zinc $(\mathrm{Zn})$, and $\mathrm{Si}]$. The samples were sent for analysis to the laboratory of the Faculty of Agricultural Sciences, National University of Colombia in Bogotá.

Statistical analyses. Analyses of variance (ANOVAs) were performed on the cumulative number of individuals and leaf nutrient concentrations data to compare treatment effects. To analyze ACP populations (cumulative numbers), the data were transformed $(\log X+1)$ because these data were not normally distributed. Leaf nutrient concentrations were also transformed using the arcsine formula because data showed a binomial distribution. When differences were observed in the ANOVA, Tukey's test of means comparison was performed. The data were analyzed using the statistical program Statistix (version 9; Analytical Software, Tallahassee, FL).

\section{Results and discussion}

Significant differences were observed in the cumulative number of ACP eggs between $\mathrm{Si}$ treatments (foliar, soil, and soil + foliar) and control in the seedlings test. Control seedlings showed differences on $\mathrm{cu}^{-}$ mulative individuals (eggs) from 2 $(P=0.026)$ and 3 WAT $(P=0.043)$. Control treatment showed a greater egg number (about 4 and 6 individuals per shoot) than $\mathrm{Si}$-treated seedlings (about 1.8 and 2.2 cumulative individuals per shoot) at 2 and 3 WAT, respectively (Fig. 2). In general, the application of $\mathrm{Si}$ treatments (either foliar, soil, or soil + foliar) reduced ACP oviposition in citrus seedlings around $60 \%$. Short-term studies ( 4 weeks) carried out by Miranda et al. (2017) with foliar spraying of insecticides (rotation of neonicotinoid, organophosphate, and pyrethroid chemical groups) showed a control around $80 \%$ of ACP adults. Ramírez-Godoy et al. (2018) found that foliar calcium carbonate sprays (a biorational insecticide) affected ACP oviposition negatively at around $60 \%$. Based on these results, Si application may be useful as part of an integrated management program for ACP because it reduces oviposition directly.

In the tree test, treatment effects were observed in oviposition starting at 1 WAT $(P=0.031)$ and for the duration of the experiment (Fig. 3). All Si treatments (foliar, soil, or foliar + soil) showed around four cumulative

Table 1. Effect of the different silicon applications (control, foliar, soil, and soil + foliar) on leaf macronutrients [nitrogen $(\mathrm{N})$, phosphorus $(\mathrm{P})$, calcium $(\mathrm{Ca})$, potassium $(\mathrm{K})$, and magnesium $(\mathrm{Mg})]$ and micronutrients [boron $(\mathrm{B})$, copper $(\mathrm{Cu})$, iron $(\mathrm{Fe})$, manganese $(\mathrm{Mn})$, and zinc $(\mathrm{Zn})]$ in tahiti lime seedlings $(\mathbf{n}=\mathbf{5})$.

\begin{tabular}{|c|c|c|c|c|c|}
\hline & \multicolumn{5}{|c|}{ Leaf macronutrient concn $[$ mean $\pm \mathrm{SE}(\%)]$} \\
\hline & $\mathbf{N}$ & $\mathbf{P}$ & $\mathrm{Ca}$ & $\mathbf{K}$ & $\mathrm{Mg}$ \\
\hline \multicolumn{6}{|l|}{ Treatment } \\
\hline Foliar & $2.54 \pm 0.10$ & $0.19 \pm 0.01$ & $2.08 \pm 0.13$ & $1.73 \pm 0.32$ & $0.24 \pm 0.01$ \\
\hline Soil & $2.78 \pm 0.15$ & $0.18 \pm 0.01$ & $1.61 \pm 0.11$ & $2.15 \pm 0.14$ & $0.20 \pm 0.01$ \\
\hline Soil + foliar & $2.45 \pm 0.32$ & $0.17 \pm 0.01$ & $1.62 \pm 0.20$ & $2.04 \pm 0.11$ & $0.20 \pm 0.01$ \\
\hline & $P=0.693$ & $P=0.472$ & $P=0.157$ & $P=0.210$ & $P=0.041$ \\
\hline & \multicolumn{5}{|c|}{ Leaf micronutrient concn $\left[\text { mean } \pm S E\left(\mathrm{mg} \cdot \mathrm{kg}^{-1}\right)\right]^{\mathrm{z}}$} \\
\hline & $\mathrm{Cu}$ & $\mathrm{Fe}$ & Mn & $\mathrm{Zn}$ & B \\
\hline \multicolumn{6}{|l|}{ Treatment } \\
\hline \multirow[t]{3}{*}{ Statistical analysis } & $\mathrm{F}=0.43$ & $\mathrm{~F}=1.70$ & $\mathrm{~F}=0.34$ & $\mathrm{~F}=3.55$ & $\mathrm{~F}=4.60$ \\
\hline & $\mathrm{df}=3,11$ & $\mathrm{df}=3,11$ & $\mathrm{df}=3,11$ & $\mathrm{df}=3,11$ & $\mathrm{df}=3,11$ \\
\hline & $P=0.739$ & $P=0.243$ & $P=0.801$ & $P=0.126$ & $P=0.066$ \\
\hline
\end{tabular}

${ }^{\mathrm{z}} 1 \mathrm{mg} \cdot \mathrm{kg}^{-1}=\mathrm{l} \mathrm{ppm}$ 
Table 2. Effect of the different silicon applications (control, foliar, soil, and soil + foliar) on leaf macronutrients [nitrogen $(\mathrm{N})$, phosphorus $(\mathrm{P})$, calcium $(\mathrm{Ca})$, potassium $(\mathrm{K})$, and magnesium $(\mathrm{Mg})]$ and micronutrients [boron $(\mathrm{B})$, copper $(\mathrm{Cu})$, iron $(\mathrm{Fe})$, manganese $(\mathrm{Mn})$, and zinc $(\mathrm{Zn})]$ in tahiti lime trees $(\mathrm{n}=4)$.

\begin{tabular}{|c|c|c|c|c|c|}
\hline & \multicolumn{5}{|c|}{ Leaf macronutrient concn $[$ mean $\pm \mathrm{SE}(\%)]$} \\
\hline & $\mathbf{N}$ & $\mathbf{P}$ & $\mathrm{Ca}$ & $\mathbf{K}$ & Mg \\
\hline \multicolumn{6}{|l|}{ Treatment } \\
\hline Control & $2.54 \pm 0.17$ & $0.17 \pm 0.01$ & $2.60 \pm 0.12$ & $1.93 \pm 0.11$ & $0.29 \pm 0.02$ \\
\hline Foliar & $2.65 \pm 0.04$ & $0.17 \pm 0.01$ & $2.35 \pm 0.20$ & $1.89 \pm 0.12$ & $0.29 \pm 0.04$ \\
\hline Soil & $2.63 \pm 0.01$ & $0.16 \pm 0.01$ & $2.54 \pm 0.06$ & $1.87 \pm 0.08$ & $0.27 \pm 0.01$ \\
\hline Soil + foliar & $2.63 \pm 0.13$ & $0.16 \pm 0.01$ & $2.68 \pm 0.11$ & $1.89 \pm 0.04$ & $0.27 \pm 0.01$ \\
\hline \multicolumn{6}{|l|}{ Statistical analysis } \\
\hline \multirow[t]{5}{*}{ Treatment } & $\mathrm{F}=0.15$ & $\mathrm{~F}=0.38$ & $\mathrm{~F}=1.24$ & $\mathrm{~F}=0.05$ & $\mathrm{~F}=0.22$ \\
\hline & $\mathrm{df}=3,11$ & $\mathrm{df}=3,11$ & $\mathrm{df}=3,11$ & $\mathrm{df}=3,11$ & $\mathrm{df}=3,11$ \\
\hline & $P=0.927$ & $P=0.769$ & $P=0.375$ & $P=0.983$ & $P=0.876$ \\
\hline & \multicolumn{5}{|c|}{ Leaf micronutrient concn $\left[\text { mean } \pm \mathrm{SE}\left(\mathrm{mg} \cdot \mathrm{kg}^{-1}\right)\right]^{\mathrm{z}}$} \\
\hline & $\mathrm{Cu}$ & $\mathrm{Fe}$ & Mn & $\mathrm{Zn}$ & B \\
\hline \multicolumn{6}{|l|}{ Treatment } \\
\hline Control & $4.58 \pm 0.54$ & $97.71 \pm 12.85$ & $23.34 \pm 2.69$ & $16.60 \pm 2.63$ & $76.44 \pm 9.80$ \\
\hline Soil application & $5.36 \pm 0.48$ & $79.44 \pm 1.77$ & $25.44 \pm 2.25$ & $28.12 \pm 9.70$ & $81.02 \pm 16.00$ \\
\hline Soil + Foliar & $4.99 \pm 0.74$ & $106.52 \pm 4.83$ & $28.23 \pm 2.40$ & $34.11 \pm 9.22$ & $84.35 \pm 16.77$ \\
\hline Foliar & $4.58 \pm 0.28$ & $78.93 \pm 13.38$ & $23.42 \pm 5.43$ & $51.39 \pm 3.59$ & $123.97 \pm 17.82$ \\
\hline \multicolumn{6}{|l|}{ Statistical analysis } \\
\hline Treatment & $\mathrm{F}=0.43$ & $\mathrm{~F}=4.00$ & $\mathrm{~F}=1.07$ & $\mathrm{~F}=3.91$ & $\mathrm{~F}=2.20$ \\
\hline & $\mathrm{df}=3,11$ & $\mathrm{df}=3,11$ & $\mathrm{df}=3,11$ & $\mathrm{df}=3,11$ & $\mathrm{df}=3,11$ \\
\hline & $P=0.740$ & $P=0.070$ & $P=0.428$ & $P=0.073$ & $P=0.189$ \\
\hline
\end{tabular}

${ }^{\mathrm{z}} 1 \mathrm{mg} \cdot \mathrm{kg}^{-1}=1 \mathrm{ppm}$.

individuals (eggs) per shoot, whereas untreated trees had 11.8 cumulative eggs.

Leaf macronutrient $(\mathrm{N}, \mathrm{P}, \mathrm{K}$, and $\mathrm{Ca})$ and micronutrient $(\mathrm{B}, \mathrm{Cu}, \mathrm{Fe}$, $\mathrm{Mn}$, and $\mathrm{Zn}$ ) concentrations in seedlings did not show differences resulting from treatments, with the exception of $\mathrm{Mg}$ (Table 1). Leaf $\mathrm{Mg}$ concentration $(0.24 \%)$ was greater in seedlings treated with foliar Si than in the other treatments (about $0.2 \%$ ). In the test on tahiti lime trees, the nutritional status (leaf macronutrient and micronutrient concentrations) was unaffected by any Si treatment (Table 2).

Leaf $\mathrm{Si}$ concentration was affected by all treatments in both tests (Fig. 4). In seedlings, the greatest leaf Si concentration $\left(2.4 \mathrm{~g} \cdot \mathrm{kg}^{-1}\right)$ was observed in the soil application treatment, whereas the control showed the lowest value $\left(1.2 \mathrm{~g} \cdot \mathrm{kg}^{-1}\right)$. In the tree test, leaf $\mathrm{Si}$ concentration was also enhanced when trees were treated with foliar and soil Si applications, obtaining a concentration of $2.3 \mathrm{~g} \cdot \mathrm{kg}^{-1}$ compared with the other treatments, which registered an average concentration of $1.4 \mathrm{~g} \cdot \mathrm{kg}^{-1}$. In general, it was observed that $\mathrm{Si}$ uptake was equal among treatments in seedlings in comparison with control;

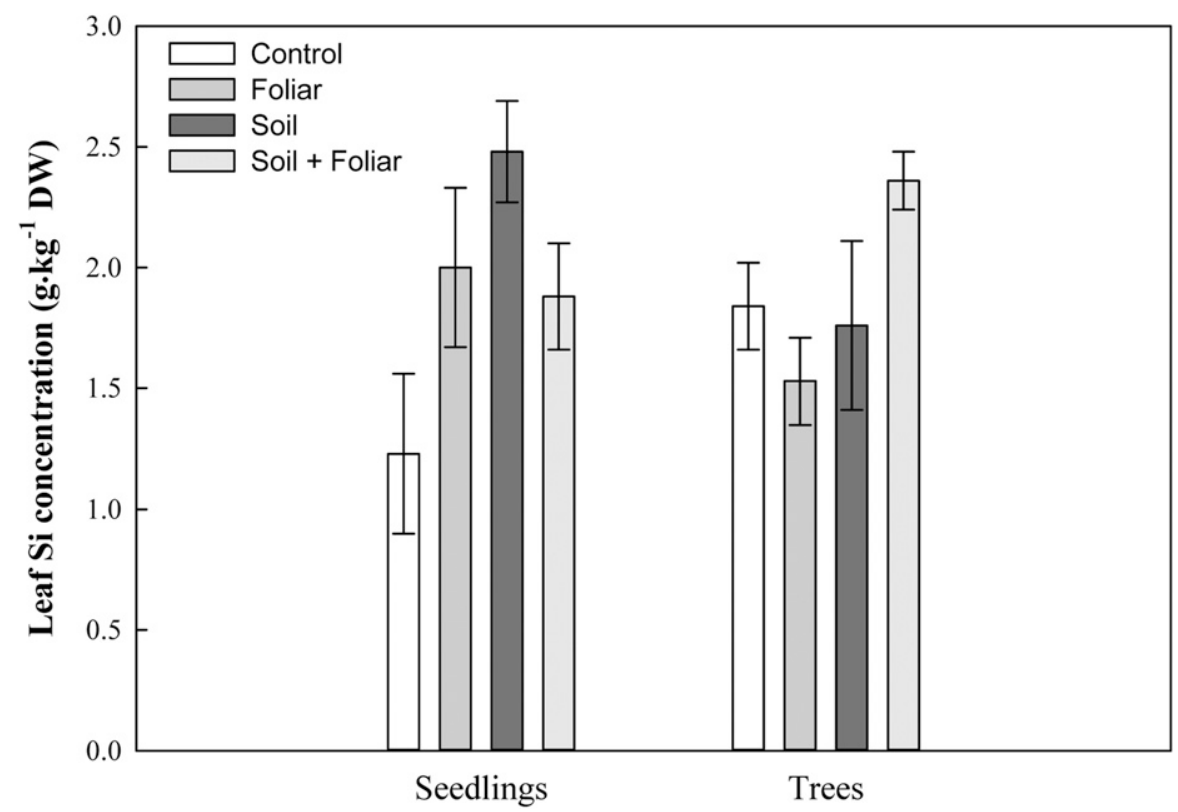

Fig. 4. Effect of different silicon (Si) applications (control, foliar, soil, and soil + foliar) on leaf $\mathrm{Si}$ foliar concentration in tahiti lime seedlings and trees. Each bar chart represents the mean of five or four values in the seedlings or trees experiment. Vertical bars represent $\pm \mathrm{SE} ; 1 \mathrm{~g} \cdot \mathrm{kg}^{-1}=1000 \mathrm{ppm}$.

however, Si concentration was different in trees receiving both foliar and soil applications compared with the other treatments.

$\mathrm{Si}$ is mainly transported from roots to shoots via transpiration stream (passive uptake) (Reynolds et al., 2016). Plant transpiration and nutrient uptake are also conditioned by factors such as temperature or water availability (Marschner, 2012). In the tree test, $\mathrm{Si}$ transport could have been limited by the combination of water-deficit conditions and warm 
daytime temperatures (Fig. 1), despite the fact that trees were supported with supplementary irrigation. In addition, foliar fertilization is a complementary tool to supply nutrients under stressful conditions (Restrepo-Díaz et al., 2008). In consequence, the previous statements can help to explain why trees with combined Si showed a better response in comparison with trees treated with soil or foliar Si application.

Although the analysis of cumulative number of adults did not show any differences among treatments, based on sampling trends it would be possible to infer that differences would have been found if sampling had continued for at least 3 weeks more. However, studies conducted by Ranger et al. (2009) and Yang et al. (2018) showed that soil Si fertilization also caused smaller adult populations of green peach aphid and spittlebugs in common zinnia (Zinnia elegans) and rice (Oryza sativa), respectively. ACP oviposition was the most affected stage by $\mathrm{Si}$ amendment on both seedlings and trees. Similarly, several authors report that one of the primary effects of the exogenous application of $\mathrm{Si}$ on the biology of sucking arthropods is on oviposition. Correa et al. (2005) reported that foliar Si applications reduced tobacco whitefly oviposition in cucumber.

The current study showed that soil and foliar $\mathrm{Si}$ applications enhanced plant resistance against ACP and also leaf $\mathrm{Si}$ concentration in tahiti lime. Our results suggest that the method that should be considered primarily by growers is soil + foliar $\mathrm{Si}$ application because it enhances leaf $\mathrm{Si}$ concentration and has an impact on ACP population. Assis et al. (2013) also reported that this combined strategy conferred resistance to sunflower plants against sunflower patch larvae.

In summary, Si application improved plant resistance to ACP populations in both tests. From all evaluated treatments, the Si combined supply caused a reduction in ACP oviposition and increased leaf $\mathrm{Si}$ concentration, mainly in trees. These findings also support previous results (Ramírez-Godoy et al., 2018) in which $\mathrm{Si}$ application acted as a physical barrier and plant resistance promoter against ACP. Based on our results, we suggest that $S i$ application can be a potential alternative for ACP management in nurseries or commercial orchards because it reduces ACP oviposition. Also, it may help to decrease the use of chemical synthesis insecticides and can increase natural enemy populations. However, further studies would be useful to estimate potential costs of $\mathrm{Si}$ applications as part of an integrated management program.

\section{Literature cited}

Assis, F.A., J.C. Moraes, A.M. Auad, and M. Coelho. 2013. The effects of foliar spray application of silicon on plant damage levels and components of larval biology of the pest butterfly Chlosyne lacinia saundersii (Nymphalidae). Intl. J. Pest Mgt. 59:128-134.

Assis, F.A., J.C. Moraes, L.C.P. Silveira, J. Francoso, A.M. Nascimento, and C.S. Antunes. 2012. Inducers of resistance in potato and its effects on defoliators and predatory insects. Rev. Colomb. Entomol. 38:30-34.

Boina, D.R. and J.R. Bloomquist. 2015. Chemical control of the asian citrus psyllid and of Huanglongbing disease in citrus. Pest Mgt. Sci. 71:808-823.

Chen, X.D. and L.L. Stelinski. 2017. Resistance management for asian citrus psyllid, Diaphorina citri Kuwayama, in Florida. Insects 8:103.

Colombian Agricultural Institute. 2015. Resolución 2390 de 2015: "Por medio de la cual se declara el estado de emergencia fitosanitaria en el territorio nacional por la presencia de adultos de Diaphorina citri infectados con la bacteria de la enfermedad del HLB de los cítricos". 9 Jan. 2018. $<$ http://www.ica.gov.co/Normatividad/>.

Correa, R.S.B., J.C. Moraes, A.M. Auad, and G.A. Carvalho. 2005. Silicon and acibenzolar-S-methyl as resistance inducers in cucumber, against the white fly Bemisia tabaci (Gennadius) (Hemiptera: Aleyrodidae) biotype B. Neotrop. Entomol. 34:429-433.

Debona, D., F.A. Rodrigues, and L.E. Datnoff. 2017. Silicon's role in abiotic and biotic plant stresses. Annu. Rev. Phytopathol. 55:85-107.

De Queiroz, D.L., J.M.M. Camargo, R.A. Dedecek, E.B. Oliveira, K.M.R. Zanol, R.C.N. Melido, and D. Burckhardt. 2016. Effect of silicon application to Eucalyptus camaldulensis on the population of Glycaspis brimblecombei (Hemiptera: Aphalaridae). Pesqui. Florest. Bras. 36: 85-94.

Ebratt-Ravelo, E.E., L.T. RubioGonzález, V.A. Costa, A.P. Castro-Ávila,
E.M. Zambrano-Gómez, and J.E. ÁngelDíaz. 2011. Diaphorina citri (Kuwayama, 1907) and Tamarixia radiata (Waterson, 1922) in citrus crops of Cundinamarca, Colombia. Agron. Colomb. 29:487493.

El-Ghobary, A.M.A. and M.F.M. ElSamahy. 2015. Efficiency of silica nanoparticles compared with certain bio-insecticides, mineral oil and insecticide on cotton bollworms under field conditions at El-Riad region. Mansoura J. Plant Protection Pathol. 6:1155-1162.

Gomes, F.B., J.C.D. Moraes, C.D.D. Santos, and M.M. Goussain. 2005. Resistance induction in wheat plants by silicon and aphids. Sci. Agr. 62:547-551.

Halbert, S.E., X. Sun, and W.N. Dixon. 2000. Asian citrus psyllid and citrus greening disease. Citrus Ind. 91:22-24.

Hall, D.G., M.L. Richardson, E.D. Ammar, and S.E. Halbert. 2013. Asian citrus psyllid, Diaphorina citri, vector of citrus huanglongbing disease. Entomol. Expt. Appl. 146:207-223.

Jenkins, D.A., D.G. Hall, and R. Goenaga. 2015. Diaphorina citri (Hemiptera: Liviidae) abundance in Puerto Rico declines with elevation. J. Econ. Entomol. 108:252-258.

Khan, A.A., M. Afzal, M.I. Ullah, A.M. Khan, and S. Saeed. 2015. Asian citrus psyllids (Hemiptera: Psyllidae), its vectored disease "Huanglongbing" and its eco-friendly management. Appl. Sci. Business Econ. 2:1-12.

Korndörfer, A.P., E. Grisoto, and J.D. Vendramim. 2011. Induction of insect plant resistance to the spittlebug Mabanarva fimbriolata Stål (Hemiptera: Cercopidae) in sugarcane by silicon application. Neotrop. Entomol. 40:387-392.

Krajewski, A.J. and S.A. Krajewski. 2011. Canopy management of sweet orange, grapefruit, lemon, lime and mandarin trees in the tropics: Principles, practices and commercial experiences. Acta Hort. 894:65-76.

Laing, M.D., M.C. Gatarayiha, and A. Adandonon. 2006. Silicon use for pest control in agriculture: A review. Proc. South African Sugar Technol. Assoc. 80:278-286.

Luo, X., A.L. Yen, K.S. Powell, F. Wu, Y. Wang, L. Zeng, and Y. Cen. 2015. Feeding behavior of Diaphorina citri (Hemiptera: Liviidae) and its acquisition of 'Candidatus Liberibacter asiaticus', on huanglongbing-infected Citrus reticulata leaves of several maturity stages. Fla. Entomol. 98:186-192.

Marschner, P. 2012. Marschner's mineral nutrition of higher plants. 3rd ed. Academic Press, London, UK. 
Matichenkov, V., D. Calvert, and G. Snyder. 1999. Silicon fertilizers for citrus in Florida. Proc. Florida State Hort. Soc. 112:5-8.

Miranda, M.P., F.L. dos Santos, R.B. Bassanezi, L.H. Montesino, J.C. Barbosa, and M. Sétamou. 2017. Monitoring methods for Diaphorina citri Kuwayama (Hemiptera: Liviidae) on citrus groves with different insecticide application programmes. J. Appl. Entomol. 142:89-96.

Nabity, P.D., R. Orpet, S. Miresmailli, M.R. Berenbaum, and E.H. De Lucia. 2012. Silica and nitrogen modulate physical defense against chewing insect herbivores in bioenergy crops Miscanthus $\times$ giganteus and Panicum virgatum (Poaceae). J. Econ. Entomol. 105:878-883.

Nascimento, A.M., F.A. Assis, J.C. Moraes, and B.H.S. Souza. 2018. Silicon application promotes rice growth and negatively affects development of Spodoptera frugiperda (JE Smith). J. Appl. Entomol. 142:241-249.

Orduz-Rodríguez, J.O. and D.M. Mateus. 2012. Overview to citrus and agronomic recommendations for cultivating these products in Colombia, p. $7-$ 48. In: L.F. Garcés-Giraldo (ed.). Citrus: Growing, postharvest and industrialization. Serie Lasallista Investigación y Ciencia, Itagui, Colombia.

Peixoto, M.L., J.C. Moraes, A.A. Silva, and F.A. Assis. 2011. Effect of silicon on the oviposition preference of Bemisia tabaci biotype B (Genn.) (Hemiptera: Aleyrodidae) on bean (Phaseolus vulgaris L.) plants. Cienc. Agrotec. 35:478-481.

Pozza, E.A., A.A.A. Pozza, and D.M.D.S. Botelho. 2015. Silicon in plant disease control. Rev. Ceres 62:323-331.

Ramírez-Godoy, A., G. Puentes-Pérez, and H. Restrepo-Díaz. 2018. An evaluation of the use of calcium, potassium and silicon for the management of Diaphorina citri populations in Tahiti lime trees. Not. Bot. Hort. Agrobot. Cluj-Napoca 46:546-552.

Ranger, C.M., A.P. Singh, J.M. Frantz, L. Canas, J.C. Locke, M.E. Reding, and N. Vorsa. 2009. Influence of silicon on resistance of Zinnia elegans to Myzus persicae (Hemiptera: Aphididae). Environ. Entomol. 38:129-136.

Rashid, M.M., N. Ahmed, M. Jahan, K.S. Islam, C. Nansen, J.L. Willers, and M.P. Ali. 2017. Higher fertilizer inputs increase fitness traits of brown planthopper in rice. Sci. Rpt. 7:4719.

Restrepo-Díaz, H., M. Benlloch, and R. Fernández-Escobar. 2008. Plant water stress and $\mathrm{K}^{+}$starvation reduce absorption of foliar applied $\mathrm{K}^{+}$by olive leaves. Scientia Hort. 116:409-413.

Reynolds, O.L., M.G. Keeping, and J.H. Meyer. 2009. Silicon-augmented resistance of plants to herbivorous insects: A review. Ann. Appl. Biol. 155:171-186.

Reynolds, O.L., M.P. Padula, R. Zeng, and G.M. Gurr. 2016. Silicon: Potential to promote direct and indirect effects on plant defense against arthropod pests in agriculture. Front. Plant Sci. 7:744.

Santivañez, T., G. Mora Aguilera, G. Diaz Pinilla, J.I. Lopez Arrollo, and P. Vernal Hurtado. 2013. Citrus: Marco estratégico para la gestión regional del Huanglongbing en América Latina y el Caribe. FAO, Santiago, Chile.

Sétamou, M., D. Flores, J.V. French, and D.G. Hall. 2008. Dispersion patterns and sampling plans for Diaphorina citri
(Hemiptera: Psyllidae) in citrus. J. Econ. Entomol. 101:1478-1487.

Singh, V. and A.K. Sood. 2017. Plant nutrition: A tool for the management of hemipteran insect-pests: A review. Agr. Rev. 38:260-270.

Stansly, P.A. and M.E. Rogers. 2006. Managing asian citrus psyllid populations. Citrus Ind. 87:17-19.

Stenberg, J.A. 2017. A conceptual framework for integrated pest management. Trends Plant Sci. 22:759-769.

Teixeira, N.C., J.O.S. Valim, and W.G. Campos. 2017. Silicon-mediated resistance against specialist insects in sapsucking and leaf-chewing guilds in the $\mathrm{Si}$ non-accumulator collard. Entomol. Expt. Appl. 165:94-108.

Tiwari, S., R.S. Mann, M.E. Rogers, and L.L. Stelinski. 2011. Insecticide resistance in field populations of asian citrus psyllid in Florida. Pest Mgt. Sci. 67:1258-1268.

Yang, L., Y. Han, P. Li, F. Li, S. Ali, and M. Hou. 2017. Silicon amendment is involved in the induction of plant defense responses to a phloem feeder. Sci. Rpt. $7: 4232$.

Yang, L., P. Li, F. Li, S. Ali, X. Sun, and M. Hou. 2018. Silicon amendment to rice plants contributes to reduce feeding in a phloem-sucking insect through modulation of callose deposition. Ecol. Evol. 8:631-637.

Ye, M., Y. Song, J. Long, R. Wang, S.R. Baerson, Z. Pan, and R. Zeng. 2013. Priming of jasmonate-mediated antiherbivore defense responses in rice by silicon. Proc. Natl. Acad. Sci. USA 110: E3631-E3639. 